\title{
Momentum Effect of Intellectual Capital On Corporate Valuation of Oil and Gas
}

\author{
Stephen I. Ocheni, PhD \\ Professor of Public Sector Accounting and Management, \\ Faculty Of Management Sciences, \\ Kogi State University. Anyingba, Kogi State, Nigeria
}

\begin{abstract}
The burgeoning fissure pragmatic amid market value and book value of myriad companies in the globe has haggard notice towards scrutinizing the value missing from financial statements. This is owed to the fact that intellectual capital (IC) shows a significant growing acceptance as a worthy topic of academic investigation and practical implication in the world. The study examines the momentum effect of intellectual capital on the corporate valuation of oil and gas companies of Nigeria. Secondary sources were explored in data collection while a regression model that aptly captures the relationship between the variables in data analysis to imprison the influence of Intellectual capital on corporate valuation in Nigeria. Furthermore, correlation analysis was applied in the assessment of the relationship between the intellectual capital and Nigerian corporate valuation. The outcome reveals that all the components of intellectual capital affect Nigeria corporate valuation. On the side of the relationship among the variables studied, the strength of their relationship is very high for all the variables. The researcher found that Intellectual capital has a positive impact on intellectual capital.Therefore; the study recommends that retention of intellects in Nigeria will be possible if an enabling business-friendly environment is provided
\end{abstract}

Keywords: Corporate Valuation, Intellectual Capital, Momentum

\section{INTRODUCTION}

Company valuation is at the center of corporate finance, and so one of the focal points of corporate organization is to exploit its value. Anuonye (2015 posits that "different company is valued differently and it depends on the aim of the valuation as well." This is why calculating a worth for a company is difficult. Current years have shown a lot of innovation in financial markets, and consequently, corporate valuation methods have not changed significantly. It is in view of the tremendous challenges posed by the global economic downturn which heralded financial meltdown that the corporate managers all over the world sought for ways of harness not only their tangible assets but also the intangible assets (Iazzolino\&Laise, 2013). One of such of such attempt is the preference of knowledge to production economy which is argued to have ushered in a paradigm shift from a period when firms were exclusively assessed on their physical assets(tangible assets) to an era of an all-encompassing platform that saw firms' worth being an aggregate of both tangible and intangible assets. This is because the 'Knowledge Economy' views Intellectual Capital of firms as an important factor. It is an essential element that distinguishes a firm's capabilities to create a sustainable competitive advantage in the market (Joshi, 2013).

As a result, firms are gasping for strategies that could stimulate corporate survival and sustainability. These circumstances culminated into the knowledge era that is driven by Intellectual Capital (IC). It is severally argued that intellectual capital has the capacity to fill the difference between market value and book value of firms. Intellectual capital if well harnesses and properly managed could strive for a more competitive advantage through enhancing value 
creation efficiency from human creativity, the firms' operational structure and customersupplier relationship (Iazzolino\&Laise,2013).

The performance of firms in the new economy depends on two elements namely the quality of knowledge and the ability of a firm to use its knowledge (Banimahd, Mohammadrezaei \& Mohammadrezaei, 2012). The question is whether IC can cause the growth potential corporate organization in Nigeria. If it has, to what extent has that impacted the economy of Nigeria using corporate valuation as a variable. It is against this background that this paper will empirically examine the momentum effect of intellectual capital on the corporate valuation of oil and gas companies of Nigeria. In other to address the setup objective, the study will test this hypothesis: Intellectual Capital does not significantly influence corporate valuation using data available at the selected oil and Gas companies in Nigeria.

\section{REVIEW OF RELATED LITERATURE}

Intellectual Capital has been widely recognized as that inherent quality regularly acquired by a firm, which drives it on the helm of value creation, value addition, and value sustainability. Nevertheless, Alipour (2012) claims "there is no universal definition of intellectual capital, but the cause and effect relationship between $1 \mathrm{C}$ and value creation is at best, indirect".

However, Thomas (1997) sees intellectual capital as the sum of everything everybody in a company knows that gives the company a competitive edge in the market place. This implies that $1 \mathrm{C}$ is that knowledge that transforms raw materials and makes them more valuable. For any knowledge to be carded ' $1 \mathrm{C}$ ', the knowledge must be able to be used to generate assets.

Edvinsson \& Sullivan (1996) and Salman (2012) posit Intellectual Capital as information, Knowledge, and acquaintance that can be transformed into value. This definition implies that intellectual capital is that employee's knowledge, capabilities, creativity, and innovation, organizational structure or relational issues that can be geared improving the organizational performance.The explanation recognized 1C as a set of intangible assets such as resources, competencies, and capabilities which increase not only firm performance but also lead to organizational value creation.

Intellectual Capital (1C) derives insights about head value, future-earning, capabilities based on Human Capital, Structural and Relational Capital. Intellectual Capital can also be viewed as a set of knowledge, information, intellectual property and expertise which can be used for the purpose of creating riches, wealth and affluence (Stewart, 1997). 1C is the sum of company's members' knowledge and practical translations of this knowledge (Roos, 2005).

\section{COMPONENTS OF INTELLECTUAL CAPITAL}

Human Capital (HC): Human Capital consists of the skills, competencies, and abilities of individuals and group (Stewart, 1997). Human Capital is interpreted as employee values creating potentials depicted in the knowledge, competencies, skills, experiences, abilities, and talents of firm's employees and managers. Human capital captures knowledge, professional skills, experience and innovativeness of employees within an organization (Iazzolino\&Laise, 2013; Banimahd \&Mohammadrezaei, 2012; Maditinos, Chatzoudes, Tsairidis \& Theriou (2011).

Structural capital: Structural capital is the knowledge assets that are indeed the company, properly and includes intellectual property such as patents, copyright, and trademarks; processes. Methodologies, models: documents and other knowledge artifacts, computer networks. 
Customer/Relational Capital: Represents the potential an organization has due to ex-firms, intangibles (Bontis, 2002). The value of relationships with suppliers, allies, and customers are classified into the forms of brand equity and customer trustworthiness (Stewart, 1997).

\section{THEORETICAL FRAMEWORK}

This study is based on Knowledge Based-View of the firms' theory. This theory was propounded by Stalk in 1992.In his postulation, competition is based on capabilities and competencies which are underpinned by knowledge. Corporate capabilities arc based on knowledge and since knowledge is a resource that forms the foundation of company capabilities, the ownership of specific knowledge provides firms with specific capabilities (Marr\&Schiuma, 2004). This study can, therefore, be related to this theory as the knowledge acquired by firms' arc the Intellectual Capital and the firms can grow their values based on knowledge acquired by harnessing its Human Capital (HC), Structural Capital (SC) and Customer/Relational Capital.

\section{EMPIRICAL LITERATURE}

Intellectual capital has been argued to be a key resource for companies to enhance competitive advantage and at the same time improve their corporate image in the global market (Salman,Mansor,Babatunde\&Tayib, M.(2012).However, there still exist a lot of arguments towards the value creation claim with no resolution on the issues yet. While some scholars strongly believe that intellectual capital positively impacts corporate values, some studies have found no relationships between $1 \mathrm{C}$ and firms values while some posit that there is a negative correlation between IC and corporate value. Not all the investigations support the positive significant relationship between intellectual capital and company's performance.

Phusavat (2011) measured the relationship between intellectual capital and financial yield found a positive, significant relationship between the intellectual capital and financial yield, and the future financial yield, and the growth rate of the oncoming financial yield of companies. Sveiby (2010) on 1C and traditional measures of corporate performance African companies used the VAIC Model but could not establish any significant correlation between $1 \mathrm{C}$ and firms' value/financial performance. The study investigated the relationship between efficiency of the value added by the major components of a firm's resource base (physical capital, human capital and structural capital) and three traditional performance measures namely; profitability, productivity and market value but empirical results failed to support any relationship between the three lines added efficiency components and three dependent variables (profitability, productivity, and market value). The findings, however, suggest that physical capital (tangible assets) remains the most significant underlying resource of corporate performance.

Amrizah \& Rashidah(2013) carried out research on the effect of intellectual capital on company's performance in Malaysia discovered that intellectual capital could account for the profitability and productivity of a firm but it couldn't explain the market value. Ngah\& Ibrahim (2012) investigated the efficacy of intellectual capital and its effect on a company's performance, and the result found a positive, significant relationship between the intellectual capital and the company's performance.

Hassan (2014) investigated the challenge in poverty alleviation: the role of Islamic microfinance and social capital and the results showed that the intellectual capital component has a positive effect on the performance of the bank, and the highest effect goes to the client capital, then stand structural and human capitals. 


\section{METHODS}

The study adopted an ex-post facto research design as it is a form of descriptive research in which an independent variable has already occurred and in which an investigator starts with the observation of dependent variable then studies the independent variable in retrospect for possible relationship to and effects on the dependent variable. The source of data was purely secondary sources from Central Bank of Nigeria Statistical Bulletin, National Bureau of Statistics Annual Abstract of Statistics and Journal articles. The data used was mainly time series data which are quantitative in nature. Based on the theoretical background that underlies this relationship, this study employed a regression model that aptly captures the relationship between the variables to capture the influence of Intellectual capital on corporate valuation in Nigeria, the empirical model that accommodates the Intellectual capital and corporate valuation nexus was specified. The Value Added Intellectual Coefficient is adopted in the computation of Intellectual capital in this study. VAIC is the sum of Human Capital Efficiency (HCE), Structural Capital Efficiency (SCE) and Capital Employed Efficiency (CEE). Using equation, the Value Added Intellectual Coefficient expressed Intellectual capital as; VA= $\mathrm{W}+\mathrm{I}+\mathrm{DP}+\mathrm{DIV}+\mathrm{T}+\mathrm{R}$

$$
\mathrm{IC}=\mathrm{f}(\mathrm{HCE}, \mathrm{SCE}, \mathrm{CEE})
$$

This function can be better expressed as follows

$$
\mathrm{VAIC}=\mathrm{HCE}+\mathrm{SCE}+\mathrm{CEE}
$$

Where, VA is the Value Added, W: Wages and salaries; I: Interest expenses; DP: Depreciation expenses; DIV: Dividends; T: Corporate taxes and R: Retained profit for the year.

On the other side of the equation, the notation relating to corporate valuation is expressed as follows:

$$
\mathrm{CV}=\mathrm{f}(\mathrm{NAPS}, \mathrm{EPS})
$$

This function can also be better expressed as

$$
\mathrm{CV}=\mathrm{NAPS}+\mathrm{EPS} .
$$

Where CV is corporate valuation in Nigeria

NAPS is Net Assets per Share

EPS is earning per Share

However, the simple regression analysis model specified for this study is given as:

$\mathrm{CV}$ (Corporate Valuation $=\mathrm{f}$ (Intellectual capital)

$$
\text { That is, } C V=\beta 0-\beta 1 \mathrm{IC}+\varepsilon
$$

Substituting the hot money expression for capital flight in our model, we have the following:

$$
\mathrm{CV}=\beta 0+\beta 1 \mathrm{HCE}+\beta 2 \mathrm{SCE}+\beta 3 \mathrm{CEE}+\varepsilon .
$$

Where $\beta 0-\beta 3$ are coefficients, and $\varepsilon$ is the stochastic 
Table1. Effect of intellectual capital on the performance of oil and gas companies in Nigeria

\begin{tabular}{|l|l|l|l|l|}
\hline Variables & Coefficients & Std. Error & t-value & Sig. \\
\hline Constant & 64.251 & 93.973 & & $*$ \\
\hline Intellectual capital (N) & 25.749 & 0.000 & 6.087 & $*$ \\
\hline R & $0.494^{\text {a }}$ & & \\
\hline R2 & 0.244 & & \\
\hline Adj R & -0.134 & & \\
\hline Std Error Estimate & 23.565 & 0.646 &
\end{tabular}

Source: SPSS Analyzed Data, 2017

*indicates significance at $1 \%$ level.

\section{RESULTS}

The result in table one shows the simple regression analysis on the effect of Intellectual capital on the performance of Oil and Gas in Nigeria. The multiple regressions co-efficient (R) was $.494^{\mathrm{a}}$ or $49.4 \%$, implying that intellectual capital was averagely correlated with the performance of Oil and Gas in Nigeria. The coefficient of determination (R2) was 0.244 or 24\%, indicating that about $24.4 \%$ of the total observed variation in the performance of oil and Gas in Nigeria was explained by the changes in Intellectual capital. The goodness of fit of the model was indicated by the high value of F-statistic (64.6). The overall model was significantly different $(P<0.05)$, suggesting that Intellectual capital exert influence on organizational performance in Nigeria.

The coefficient of Intellectual capital was negatively signed as well as statistically significant at 1\%. This means that a unit decrease in Intellectual capital will lead to 25.479 decreases in performance of Oil and Gas in Nigeria.

\section{Test of Hypothesis}

The null hypothesis which states that there is no significant effect of Intellectual capital on the performance of Oil and Gas in Nigeria was tested using the F-statistics.

Decision rule: If F- cal > F- tab, reject the null hypothesis otherwise accept. The F-cal value (64.6) is greater than the F-tab value (4.08), the null hypothesis is rejected, and the alternative hypothesis is accepted that the Intellectual capital has a significant effect on organizational performance in Nigeria.

The objective of the study is to ascertain the effect of Intellectual capital on the organizational performance of Oil and Gas in Nigeria. Our findings revealed that Intellectual capital has a significant effect on organizational performance in Nigeria. Results of the study equally show that a unit increase in Intellectual capital will lead to an increase in organizational performance in Nigeria. This finding is in agreement with the outcome of the study of Salman el.al (2012) and Sveiby (2010). However, their studies were mainly on Intellectual capital and economic growth and development in Nigeria and not necessarily on organizational performance. On the other hand, we thought it wise to relate corporate valuation and economic growth and development knowing very well that organizational performance is one of the major drivers of economic growth and development in any country. However, the result of Phusavat (2011) concludes that Intellectual capital has a positive impact on capital flight. In other words, increase in the Intellectual capital has a positive impact on Intellectual capital, but our finding revealed that increase in Intellectual capital reduces corporate valuation in Nigeria.

Therefore, the study recommends that retention of intellects in Nigeria will be possible if 
enabling and the business-friendly environment is provided. This will be achieved through the provision of the infrastructural facilities such as good road, water, and electricity. Also, business environment should be made friendly through the enactment of good policies that will go a long way to stem the political turbulence in the country and by doing so best brain in the management of oil and gas will find their square root back to Nigeria. More so, kidnapping, Boko haraming, and terrorist groups should be eradicated to avoid depletion of intellects that sometimes lead multinational companies to seek for greener pasture abroad.

Double taxation relief agreement should be judiciously applied to ensure that corporate organizations are not unduly taxed to minimize intellectual capital outflow from Nigeria. Nigerian government should equally establish monetary and fiscal policies that will be able to stabilize the economy. This is in view of the fact that unstable economy is one of the causes of Intellectual capital outflow.

Finally, Nigerian government should enforce economic policies that can encourage domestic investment and discourage Intellectual capital so as to step up the GDP level from in Nigeria. For instance, placing a limitation as to the amount or percentage of local profit that could be repatriated to parent company from the subsidiary will help to reduce the exodus of Intellectual capital from Nigeria.

\section{References}

Alipour, M. (2012). The effect of intellectual capital on firm performance: an investigation of Iran insurance companies, Measuring Business Excellence, 16(1), 53-66.

Amrizah, K., \& Rashidah, A. R. (2013). Intellectual Capital Profiles : Empirical Evidence of Malaysian Companies Kamaluddin \& Rahman. International Review of Business Research Papers,9(6), 83-101. Retrieved from http://irbrp.com/static/documents/November/2013/6. Amrizah.pdf

Anuonye, B.N. (2015). Intellectual capital measurement: Using the Earnings per share model of quoted insurance companies in Nigeria, 10(1) 88-98.

Banimahd, B., Mohammadrezaei, F., \& Mohammadrezaei, M. (2012). The Impact of Intellectual capital on profitability, productivity and market valuation: Evidence from Iranian high-knowledge based industries. Journal of Basic and Applied Scientific Research. 2(5) 4477- 4484.

Bontis, N. (2002) World Congress on Intellectual Capital Reading. Butterworth-Heinemann, Boston.

Edvinsson, L., \&Malone, M. (1997). Intellectual capital: Realising your company's true value by finding its hidden brain power, Journal of Human Resources Accounting. 4(1) 21-33.

Hassan, A. (2014). The challenge in poverty alleviation: the role of Islamic microfinance and social capital. Hu manomics,30(1), 76-90.doi:10.1108/H-10-2013-0068

Iazzolino, G., \& Laise, D. (2013).Value-added intellectual coefficient (VAIC). A methodological and critical review. Journal of Intellectual Capital.14(4) 547-563.

Joshi, M. (2013).Intellectual capital and financial performance: an evaluation of the Australian financial sector. Journal of Intellectual Capital.14(2) 264-285.

Marr B, Schiuma G, Neely A. 2004.The dynamics of value creation: Mapping your intellectual performance drivers. Journal of intellectual capital.5 (2)312-325.

Rose B. (2005). The Effect of Disclosing Intellectual Capital (The Core Asset for the Third Millennium Economic entities) on the Internal and external financial Statements, Users, 2005.

Salman, R.T, Mansor, M and Babatunde, D, A. and Tayib, M.(2012). Impact of intellectual capital on return on assets in Nigeria manufacturing companies. Interdisciplinary Journal of Research in Business; 2(4), 21-30.

Stewart T.1997.intellectual capital: The new wealth of Nations. Doubleday Dell Publishing Group, New York. (2)10.

Sveiby, K.E. (2010).Methods for measuring intangible assets", [online], available at

http://www.sveiby.com/articles/IntangibleMethods.htm 